\title{
Renaissance Queens and Foucauldian Carcerality
}

LISA

HOPKINS

Summary: This essay examines the figuring of images and experiences of imprisonment in the public and private writings and speeches of three women - Marguerite de Navarre, Mary, Queen of Scots, and Elizabeth I - and a man, Sir Philip Sidney, writing to an explicitly feminised agenda. It explores the ways in which the differing belief systems of Protestantism and Catholicism inflected the meanings constructed for carcerality, and the extent to which it could be perceived as an instrument of reform rather than merely detention.

$\mathrm{M}$

ichel Foucault, in his wide-ranging study of the theories and practices which have turned us into a carceral society, sees the first institution specifically designed for the housing of offenders as the Rasphuis in Amsterdam, opened in $1596,{ }^{1}$ but dates the widespread practice of detention of criminals to a much later period than this, centring on the French Revolution (pp. 115-116). During the preceding early modern period, he argues, and especially during the sixteenth century, the body of the criminal was not detained but dismembered, in a horrific public display of the overwhelming power of the State which he had challenged: "the aim was to make an example, not only by making people aware that the slightest offence was likely to be punished, but by arousing feelings of terror by the spectacle of power letting its anger fall upon the guilty person" (p.58). Thus, for punishment such as this, the point of the exercise demands two elements in the treatment of the guilty: that they suffer hideously, and that they must be seen to do so - "the body of the condemned man was ... an essential element in the ceremonial of public punishment" (p. 43).

Although his evidence is drawn primarily from France, Foucault applies his theories to early modern Europe as a whole, and refers in passing to 
instances from several other countries, including England. It is, beyond doubt, the case that Foucauldian ideas of the scaffold as a theatre of power are clearly applicable to the many instances of horrific public deaths suffered in England by those labelled "traitors" to the crown. Nevertheless, both English and Scottish history also afford several notable instances of power choosing to hold back from the full force of such a display and to turn instead to the use of carcerality, considerably earlier than those instances of it cited by Foucault and operating in rather different ways from those he primarily outlines. It is the cases of those early prisoners, and primarily two of the most famous of them, Elizabeth I and her cousin Mary Queen of Scots, which I wish to draw on here, exploring not only how they can be related to Foucauldian theories of carcerality but also the ways in which their actual imprisonment and their concepts of carcerality are both conditioned by and figured in public and private writing, both by and about them, by another woman, Marguerite de Navarre, and by a man, Sir Philip Sidney, explicitly writing to a woman's aesthetic agenda.

The idea of keeping people in prison is of course a well-established one in English history, but it is almost invariably conceived of as a temporary measure, preventing people from escaping until they can be executed, can pay their debts, or are ransomed. Prison in these circumstances is perceived primarily as a restraint of liberty; there is no suggestion of any rehabilitatory element. There is a class dimension to its use in this way, since the lower orders are more likely to be kept until they are killed or pay off their debts, while there may well be other reasons involved in the detention of the upper echelons of society: Edward II, Richard II, Henry VI, Edward IV and Edward V were all incarcerated for reasons of State, and this practice became increasingly widespread under the Tudors. Whereas the feuding Yorkists and Lancastrians in the Wars of the Roses had been prone to executing their defeated enemies on the field of battle, the Tudors (with the notable exception of Henry VIII) habitually fought shy of bloodshed, usually preferring to consign opponents to the Tower until they died or ceased to be perceived as dangerous. Thus at various times during her reign Elizabeth I had the Earls of Northumberland, Arundel and Hertford and her cousin the Duke of Norfolk kept as prisoners of State, and although she was eventually driven to resort to the block in the case of Norfolk, Arundel and Northumberland both died in the Tower (Northumberland probably by his own hand), and Hertford was released.

If there was a clear class bias in the purposes of early modern English carcerality, however, it is equally possible to trace a pattern of gender difference. Most English monarchs displayed far greater reluctance to im- 
prison women than they did men, and when they did so they treated them in markedly different ways. When the last Prince of Wales, Llywelyn yr Olaf, died in an ambush, Edward I had his infant daughter and niece placed in convents to ensure the extinction of the bloodline, and though this was in fact tantamount to life imprisonment, it was easily possible to present it very differently. King John imprisoned his nephew, Arthur, and his niece, Eleanor; but whereas Arthur claimed the throne directly, Eleanor could merely transmit such a claim, and while he was killed she was imprisoned for life in Bristol Castle. Henry VIII earned particular vilification for his treatment of the aged Countess of Salisbury, the last surviving Plantagenet princess and his own cousin, when he had her first imprisoned and then beheaded at the age of 80 , and his successors were noticeably more careful in their treatment of highlyranked women offenders. Mary I wished even to reprieve Lady Jane Grey until she was dissuaded by the Spanish ambassador, and Lady Jane's mother, Frances, Duchess of Suffolk, and her younger daughters Lady Catherine and Lady Mary were all spared the penalties visited on their menfolk. ${ }^{2}$

Some of the reasons for this differential treatment are obviously grounded in the contemporary ideologies which saw women as the weaker, less responsible sex, and as being, paradoxically, both innately more prone to evil and so as less blameworthy for it. Other considerations, however, are clearly apparent in Elizabeth I's treatment of those women who offended her. When her cousin Lady Catherine Grey married the Earl of Hertford without her permission, the young couple were both imprisoned, and strict orders were given to keep them separate, for the danger of the marriage lay in Lady Catherine's position as heir presumptive to the Crown, and Elizabeth clearly did not wish to bolster this by allowing Lady Catherine to produce a son. This strategy in fact failed, for owing to lax supervision the couple saw enough of each other to produce not one but two boys, and at this point Elizabeth had.Lady Catherine removed from the Tower altogether and given into the keeping of her uncle, where she remained until her death. The same thing recurred with the third Grey sister, Lady Mary, a sufferer from dwarfism, who secretly married Elizabeth's sergeant-porter Thomas Keys. She too was ordered to be closely guarded by a relative, in this case her step-grandmother the Dowager Duchess of Suffolk, until her early death.

In both these cases, the central issue for Elizabeth was clearly control of any reproduction of the threat posed to her by her cousins; it was, in a very literal sense, the Grey girls' bodies that were being guarded, as it had been for Eleanor of Brittany and for Gwenllian of Wales. Yet the choice of the Dowager 
Duchess of Suffolk as Mary Grey's guardian also suggests that attention was perhaps to be paid to her soul as well, since the Duchess was celebrated as a radical Protestant who had fled into Continental exile during the reign of Mary I. The rigour and introspection encouraged by Protestantism could certainly have been expected to result not only in simple restraint but also in penitence on the part of the prisoner. Perhaps something of the same mechanism was also at work in Elizabeth's decision to send to the Tower another woman involved in the Grey debacle, Elizabeth Hardwick, Lady St Loe (later better known as Bess of Hardwick) who had unwillingly been made Catherine Grey's confidante. Elizabeth certainly had no intention of executing Lady St Loe; her purpose was presumably rather to frighten her, and thus lead her to modify her behaviour in the future. This too can be interpreted as reformative carcerality, but in a rather different sense. Mary Grey would have no opportunity to repeat her offence, and so any remorse evoked in her would be purely for the good of her soul, whereas carcerality as an attempt to discourage recidivism obviously partakes more of the realities of this world than of those of the next. In this sense, Elizabeth St Loe's imprisonment is more like those of the male courtiers such as Hertford, Southampton and Raleigh, who found themselves behind bars for periods of varying brevity, usually for sexual offenses, to be released when it was felt they had been sufficiently frightened to behave better in the future.

In the case of the most famous of all Elizabethan prisoners, issues of gender and status combined to make the case uniquely difficult to deal with. When Mary, Queen of Scots fled across the Solway Firth to England, she appears never even to have suspected that Elizabeth's response might be to incarcerate her. Yet it was from imprisonment that she had just fled, escaping from the island fortress of Lochleven in a boat, and she could perhaps have reflected that it was, historically, almost always the answer, in England, to the problem posed by deposed monarchs. Edward II had been sent to Berkeley, Richard II to Pontefract, Edward IV to Warwick Castle, and Henry VI and Edward V to the Tower. In all these cases, imprisonment had of course never been perceived as a permanent solution. These kings were certainly not seen as individuals in need of reform - Edward V was a child, Henry VI widely acclaimed as a saint; they were, rather, being treated as political, not personal, entities, and in every case but one the logical way out had been murder. Edward IV alone had escaped, and that largely because no strong successor emerged to give the order, as Edward himself would later do for Henry VI.

Mary, Queen of Scots was not, however, a deposed English monarch. Rather, she occupied an uneasy middle ground between two contradictory 
positions. Unwanted monarchs of Scotland had tended to die outright, as happened with James I, victim of an assassination attempt, and James III, mysteriously stabbed by a never-identified assailant while fleeing after a battle. It was probably Mary's gender, perhaps combined with a pregnancy, which saved her from such a fate. As well as Queen of Scotland, however, she was also pretender to the English crown. There had been several of these in the past, and in the treatment of many an element of reform can be observed. Lambert Simnel was offered a place in Henry VII's household; Perkin Warbeck was given an unusual second chance by the same king, not being ultimately put to death until after repeated escape attempts; Mary I initially proposed to allow Lady Jane Grey to live, and tried earnestly to offer her what she perceived as rehabilitation by making every effort to persuade her to convert to Catholicism, and so save her soul. ${ }^{3}$ While reasons of state might virtually automatically decree the death of former kings, there was clearly an impulse to spare pretenders, which may in fact have been partly prompted by the desire to draw a clear distinction between their own unimportance and the dignity of the role to which they had falsely laid claim.

Neither of these strategies was appropriate for coping with Mary, Queen of Scots, though there are certainly elements of the second in Elizabeth's dealings with her. As sovereign queen of another county, she had to be accorded a certain respect; she was not Elizabeth's subject, which made the question of Elizabeth's rights over her person highly problematic, and it was, additionally, highly undesirable for the queen to condone regicide by having her put to death. Equally, although Elizabeth's initial response of sending her clothes more fit for a maid than a queen might seem to echo the strategy of dealing with pretenders by downplaying their importance, Mary was not a pretender; while there might be questions about her morality, there could be none about her identity. Lastly, there was in her case an additional complication about the standard concern with royal females, the question of reproduction. Mary had already borne a son, who was alive and well and ruling, even if only nominally, in Scotland. In some ways, this made the policing of her body redundant, but there was always the possibility that James might die, and the continual buzz of gossip about possible husbands for Mary, including Don John of Austria and the Duke of Norfolk, would have served to keep the issue alive. Moreover, while the existence of James meant that Mary must be treated carefully, since her son must be placated and kept friendly to his English neighbours, it equally made her continued detention desirable, since James' filial affection did not extend to a desire to see his mother return and supplant him. 
Mary, then, was put in prison. Whether consciously or unconsciously, Elizabeth echoed in this her own father's treatment of another redundant royal female with powerful male relations, Catherine of Aragon, for just as Catherine had been, Mary was deliberately confined in places thought draughty and unhealthy enough to be likely to precipitate her end (few then, as now, escape unscathed from a Sheffield winter!). ${ }^{4}$ Whereas this plan had succeeded with Catherine, though, it failed in Mary's case. Certainly her health was seriously undermined - she suffered increasingly from attacks of the hereditary metabolic disorder porphyria, aggravated by stress, grew stout, and at her death was found to be bald - but she lived stubbornly on. When this tactic had earlier been unsuccessfully attempted on a deposed English ruler, Edward II, whose robust constitution had apparently sustained him even when forced inside a sewer, violence had eventually been resorted to: as Marlowe's play would later remind Elizabethans, Edward had been murdered with a red-hot poker. There is indeed evidence that Elizabeth did actually try to have Mary secretly murdered, but, unlike numerous predecessors, was unable to find anyone to do it. Possibly she was rather half-hearted in the attempt, but the episode does also suggest that not only Mary's gender but, ironically, the very nature of reforming carcerality protected her: the keeper who refused the queen's request, Sir Amyas Paulet, had been picked precisely for his moral uprightness and strict adherence to Protestantism, standards which he was not prepared to compromise even for his queen. ${ }^{5}$

The Paulet incident raises the whole question of the meanings to be made of Mary's imprisonment. On one level, it was clearly a simple question of pragmatism: since Elizabeth wished neither to kill nor to release her, she had no choice but to incarcerate her. On another, however, there were clearly also elements of behaviour modification involved. Elizabeth intermixed the detention usually reserved for kings with the humiliation traditionally meted out to pretenders, trying psychologically to undermine Mary by repeated attempts to withhold as many as possible of the customary privileges of her rank. Mary herself perceived this as little more than sadism, especially when it came from the puritan Paulet; he himself, however, might well have seen it as a salutary exercise in the humbling of an over-proud spirit, and a Catholic one at that. In her own country, after all, Mary had been branded both murderess and whore, and there would have been few who did not believe her guilty of at least one of the those crimes.

What is more striking, however, is that Mary herself seems to have been disposed to perceive an element of reform in what she in general regarded as her totally unjustifiable detention. In her poems, she addresses God as one who: 
En retirant de ce monde mon coeur

Fais l'aspirer à l'éternel bonheur.6

In "Sonnet ecrit au chateau de Fotheringhay" she elaborates the idea further, when she exhorts her friends:

Souhaitez donc fin de calamité

Et que, ici-bas étant assez punie,

J'aie ma part en la joie infinie ${ }^{7}$

Here the conceit is clear: her earthly detention by Elizabeth may be allowed to stand as part of the time she would otherwise have spent in purgatory. It is, in short, not simply an incarceration of the body; it may also have had effects on the soul. Interestingly, this correlates closely with what Foucault argues not about detention but about torture in the early modern period, that "the pains here below may ... be counted as penitence and so alleviate the punishments of the beyond: God will not fail to take such a martyrdom into account, providing it is borne with resignation." 8

Ultimately, of course, the imprisonment of Mary, Queen of Scots was a political failure Elizabeth's control of her rival's body did not allow her to prevent schemes and intrigues, and, eventually accepting that, while Mary lived, she would provide a figurehead for Catholic conspiracy, Elizabeth with great reluctance agreed to her execution. Mary had ironically prefigured her own fate in the great pastime of her incarceration, her needlework: one of her embroidered panels shows herself as a mouse while Elizabeth, figured as a marmalade cat, waits to pounce. ${ }^{9}$ Elizabeth's leap for the kill, however, provides another striking example of English penal practices differing from the Foucauldian norm. Foucault sees the entire point of the inscription of state power on the body of the criminal as being that "it is first inscribed in the legal ceremonial that must produce, open for all to see, the truth of the crime." ${ }^{10}$ In keeping with an increasing tendency towards private punishment, Elizabeth had Mary executed most discreetly. This was in notable contrast to the relative publicity of her trial, which, although carefully staged and controlled, was open to both the inhabitants of Fotheringhay village and the servants of the commissioners appointed to it (albeit on one side of a wooden barrier, and only as many as could fit into the 24 feet of the great hall of the castle which had been left vacant for the purpose); for the whole trial was geared entirely towards compromising the queen's regality firstly by her very presence at it and second by relegating her to the opposite end of the hall from the dais under which her judges sat. ${ }^{11}$ 
For the execution itself, however, greater secrecy obtained. Whereas the feuding Yorkists and Lancastrians had had each other publicly beheaded in market places, the Tudors had developed a marked preference for the comparative privacy of Tower Green. The execution of Mary, however, was the most secluded yet, for it actually took place in the great hall of Fotheringhay Castle (this instead of the more usual castle green, was Elizabeth's own choice), ${ }^{12}$ in front of an audience whose role was rather to verify the truth of the event than to learn any lesson from it: although local dignitaries and even ordinary inhabitants were again allowed to attend (one account estimated that there were up to 300 spectators present), it was at first ruled that Mary's own servants were to be forbidden entry to the hall, on the grounds that they might seek to obtain relics of her - and doubtless also because, as Mary herself pointed out, "they could later report the manner of her death in other countries." ${ }^{13}$ Much secrecy had attended the comings and goings of those to be involved: tales of misleading warrants of hue-and-cry, to cloak the true purpose of the journey of Elizabeth's agent Beale to the castle, and of the executioner having to be secretly lodged at an inn, give the whole affair a distinctly cloak-and-dagger air. Rather than seeing the occasion as a propaganda opportunity for herself, Elizabeth seems to have feared instead that it could in fact turn into one for her enemy, or that, in any event, the death's meaning might be produced in ways which she herself did not control. One such way was clearly available within the Catholic belief system espoused by Mary: she might become a martyr (as is indeed suggested by the proposed exclusion of the servants, and by the careful preservation of one of the garments in which she was executed at Coughton Court in Warwickshire, stronghold of the Catholic Throckmortons, where the wives of the Gunpowder Plot conspirators were later to await the news of their husbands' success). ${ }^{14}$ The utter destruction of Fotheringhay after her death was clearly intended to prevent this, as was her hugger-mugger interment at Peterborough, ironically opposite another Catholic queen, Catherine of Aragon; but all these measures were negative ones, designed to counter ideological productions rather than to foster them. There is no "official" account of the execution, no discernible programmatic agenda underlying those of its details which can be reconstructed (others, such as whether or not music was played, seem destined to remain for ever vague). ${ }^{15}$ Try as she might, Elizabeth could make no meaning of her own of Mary's death. Its very necessity demonstrated all too clearly that Mary's imprisonment had had no reforming effect on her; and if death was to be ultimately necessary, it would be only too tempting to regard as wanton cruelty the policy that had deferred it for 19 unhappy years. 
Mary's imprisonment and eventual execution thus reveal not only an outstanding example of the practice of early English carcerality, but also the absence of any workable theories of it. In Sir Philip Sidney's The Countess of Pembroke's Arcadia, the imprisoned Pamela sews, just as Mary did, to pass away the time; but when commended for her work, she replies, "I promise you I wrought it but to make some tedious hours believe that I thought not of them." ${ }^{16}$ Later, in one of the most extraordinary scenes of the work, Pamela is apparently executed (it is in fact a masked substitute who is beheaded) in the great hall of the castle in which she is being detained, while a kind of Foucauldian panopticon is created by the drawing back of the curtains covering the internal windows in the cells of her sister Philoclea and their companion, which look out into the hall. The aim of this charade is to terrify Philoclea into marrying her cousin Amphialus; when it fails, the ritual is repeated, with variations - Philoclea is forced to stand under the scaffold with her head protruding so that she appears to have been decapitated, and this time it is Pamela who must watch the masquerade. However, Pamela, too, is unmoved; the incident proves a failure, a narrative and stylistic red herring. As the princesses are released, events begin to move towards a resolution, and the work reverts to a more urbane, comic tone. The bizarre grand-guignol of the mock executions thus stands alone in it, an isolated, unintegrable moment, just as the imprisonment of Mary Stuart remained similarly irreconcilable: what Sidney figures is the ultimate futility both of carcerality and of the show of power, and he does so, interestingly enough, in a work written expressly to please a woman, his sister, Mary, Countess of Pembroke. The entire episode of the sisters' detention and mock execution is not even hinted at in The Old Arcadia, the original version of the work; it is only Sidney's revision, written at his sister's home, Wilton, and nominally at least under her aesthetic supervision, which inserts it. What was its appeal supposed to be for the Countess?

Prophetic though it may have been of the eventual end of Mary, Queen of Scots it can have no direct connection with it, for Sidney's own death preceded the captive queen's, and there can be no reason to imagine that his sister's later reworkings extended to revisions of this magnitude. Nevertheless, the detention and mistreatment of royal females cannot have been less than topical, especially to a man like Sidney, whose political agenda involved a reconciliation between the sundered poles of Protestantism and Catholicism. The other substantial alterations during the revision centre largely on the character of the two princes who act as its heroes - Musidorus, in particular, is reformed from 
a frustrated rapist in the early version to a model of bashfulness - and perhaps the episode of the nock-beheadings, which seems at first sight so much like a deviation from serious purpose, in fact belongs to much the same set of criteria which prompted the redrafting of the princes, offering the work as politically-driven commentary rather than sheer escapism (its very conception, after all, owed its existence to an enforced gap in Sidney's own political career, occasioned by the queen's anger at his interference in the question of her marriage). If so, the greater prominence given to the imprisonment of women should be seriously read; and its message would appear to be clear as in Mary's own poetry, detention can serve only a spiritual function, humbling the patience of the proudly-inclined Pamela, and not a political one. At best a stopgap, at worst a cruel and unusual punishment, it operates primarily as a ploy to gain time, or in the hope of manipulating the outcome of future events, and while a spiritual dimension might be rudimentarily apparent, the most obvious element of early modern carcerality is its own bondage to time, and its vulnerability to interpretations hostile to rather than supportive of the ideologies of those who practised it.

Of course, it is figured precisely as such a non-time in the opening lines of one of the most famous of all female-authored commentaries on imprisonment, Elizabeth I's own poem on the imprisonment of Mary Queen of Scots:

The doubt of future foes

Exiles my present joy,

And wit me warnes to shun such snares

As threaten mine annoy. ${ }^{17}$

Prison figured very largely in both the writing and the life of Elizabeth. Appropriately enough, her very first literary effort had been a translation of Marguerite de Navarre's Miroir de l'ame pecheresse, made as a gift for her fourth and last stepmother, Catherine Parr, and offered to the Queen with a cover embroidered by Elizabeth's own hand. For the Pearl of the Valois, prison had been one of the dominant metaphors of the oeuvre, featuring most obviously in her final work Les Prisons and her "Complainte pour un detenu prisonnier," and in this as in her other work she may well have influenced Elizabeth's own thought: as Elizabeth Balestrieri comments, "both queens continually subverted the various societal 'prisons' designed from without to check them, by using the power of the Word (of God), itself undergoing reformations, to empower their texts." 18

By a singular irony, it may well have been Elizabeth's own ill-fated mother, Anne Boleyn, who obtained a copy of Le miroir de l'ame pecheresse 
from Marguerite herself, before ending her own days in the royal prison of the Tower. ${ }^{19}$ For Marguerite, prison loomed everywhere; she saw her marriage as one,$^{20}$ she had to suffer the detention first of her adored brother François I in a Spanish prison and then the prolonged incarceration of his two young sons in his place, and she also records her deep distress at the fate of the anonymous "un détenu prisonnier," once thought to be François I himself but in fact, Abel Lefranc has convincingly argued, her friend Clément Marot, author, appropriately enough, of $L$ 'Enfer. ${ }^{21}$ Even affection is described, in her work, in carceral terms: Samuel Putnam writes, "her first 'prison' had been a shimmering 'tour d'amour,' a sun-flooded dungeon of love," ${ }^{22}$ and she speaks of it in terms which interestingly counterpoise metaphorical and literal connotations:

Donques pensez si ma prison cruelle,

En vous voyant partout, me sembloit belle.

Si vostre oeil fut mon lyen et ma corde,

Vostre parler, que souvent je recorde,

Fut mes durs fers et ma pésante chaisne,

Qui me faisoit ainsy qu'en forte gehenne ...

Et si taisoys ce que je voulois dire,

En désirant alonger mon martyre. ${ }^{23}$

Starting with love, this moves rapidly through to a more spiritual reading of the experience, speaking of "hell" and "martyrdom." Marguerite's obsession with prison was indeed deeply related to her spirituality, for her Huguenot preferences (which, shared by Marot, were the cause of his imprisonment) are abundantly apparent in both Les Prisons and the "Complainte pour un detenu prisonnier." Lefranc declares of the former work that it is radically informed by "l'épopée protestante que Marguerite avait devinée et entrevue, et à laquelle elle avait manifestement préludé par les trois chants de ses mystérieuses Prisons," 24 and of the latter that "dès ce debut, d'une allure si noble, l'hommage rendu au Christ médiateur nous fait pressentir les sympathies réformées de celui qui va nous confier ses tristesses."25

Into this traumatic experience, the personae of Marguerite's poems attempt valiantly to infuse meaning. The nameless prisoner of the "Complainte" affirms:

Certes je croy que par ton mandement Fortune a fait contre moy son effort. ${ }^{26}$

He admits that his suffering is certainly deserved: 
Si tu voulois la peine mésurer Jouxte mes faitz, me faudroit endurer Nom un enfer, mais mille millions, Pour tant de maux, delictz, rebellions Que j'ay commis en trespassant ta Loy. ${ }^{27}$

Nevertheless, it is tellingly ironic that the prisoner seems, almost certainly with Marguerite's connivance, to have escaped from his gaol, which strongly suggests that the declaration of belief that his imprisonment is God's will represents rather an attempt to comfort than a serious credo. Moreover, the repeated association of prison with hell serves to drain it of any recuperative potential: no purgatory, it is subject rather to the quasi-pagan force of Fortune, and the idea that it might bear some correlation to the prisoner's spiritual state is evoked only to be negated, with the dismissal that it is not sufficiently punitive. The carceral experience offers even less hope of spiritual progress in the considerably more abstruse Les Prisons, where the stress on its metaphorical as well as its literal nature frequently suggests that it should be read as a delusory state of spiritual despair, more akin to the Slough of Despond, as a mental frame from which one must shake free, than to any kind of educative experience.

Prison becomes even more drained of meaning in its representation in the writings and speeches of Elizabeth I, who was so acquainted with both its privations and its uses. Her attitude to it was, in one sense, severely practical: Foxe relates that she bore no grudge towards her gaoler at Woodstock, and indeed "told him, when Queen, that she would be delighted to send him any prisoner who needed to be 'sharply and straightly kept.' In her litany of nicknames - always a sign of her affection — he remained 'her gaoler,' and she once stayed at his house in Norfolk." ${ }^{28}$ The promise to use him in future clearly registers that Elizabeth understood the political necessity of prison; in her own case, however, she claimed precisely not to understand the nature of the experience when she told the guard who were conveying her to the Tower, "I marvel what the nobles mean by suffering me, a prince, to be led into captivity, the Lord knoweth wherefore; for myself, I do not."29 "Marvelling" and "not knowing," Elizabeth represents herself as innocent equally of crime and of the intellectual apprehension of her situation. A similar disingenuousness characterises other examples of her attitude to prison. Collections of her writings and speeches abound with references to her own imprisonment; they contain no single use of the word with reference to the woman she herself kept a prisoner, Mary, Queen of Scots, though she does refer to Mary as "in prison" 
during her period of detention in Scotland.$^{30} \mathrm{Her}$ language is equally slippery when it comes to Mary's ex-husband, Bothwell, incarcerated in Elsinore until he died insane: Elizabeth wrote to Frederick II of Denmark that Bothwell, "as we have heard, by your Serenity's command is in safe keeping in Denmark." And the same coyness characterises her description of her own treatment of Essex: "the Earl is well lodged at one of his friends, with a beautiful room and a garden to walk in." 32

Elizabeth's spiritual development after her initial encounter with the thought of Marguerite de Navarre was again informed by carcerality when she set herself to translating the Consolation of Philosophy, written by Boethius when in prison. Boethius also formed the model for her original poem written on a shutter in Woodstock. Frances Teague comments of this:

Like Boethius, Elizabeth was a prisoner when she wrote her poem. In the lyric, her love for Boethius combines with her sense of unjust treatment. Following the Christian stoicism of Boethius, Elizabeth believes that Fortune governs human affairs and that the rule of Fortune sometimes allows freedom for the guilty and imprisonment for the innocent (like herself). But since men are caught of Fortune's wheel, little can be done to alter this state of affairs. This viewpoint is an orthodox one, though one notes that the last line of her shutter poem and the couplet "On Fortune" both express faith that God will recognize her virtue and send her foes "all they have taught."

Once again, Elizabeth is militantly innocent; she has nothing to learn from her experience. It merely represents a chance turn of Fortune's wheel, and as such, it will ultimately be reversed. The spiritual is invariably imbricated in the political in Elizabeth's thought: Tucker Brooke comments aptly that even in her latest work we can detect "some persistence of the twelve-year child's confusion between her earthly and heavenly father ... The God she prays to is a sovereign of wrath and unsearchable ways, who can, however, be counted on to support the Tudor policy and rejoice with his daughter when she outwits her enemies." 34

Not only spiritually, then, but politically, imprisonment performs, ultimately, no function at all. Only within the discourse of religion can some modicum of meaning be recuperated for it, and there the Protestant perspective of Elizabeth allows her to see it only in terms of punishment for others, rather than a period of trial for herself:

Thou causedst the guiltie to be losed

From bandes, wherein are innocents inclosed:

Causing the guiltless to be straite reserved, 
And freeing those that death had well deserved.

But by her envie can be nothing wroughte,

So God send to my foes all they have thoghte.

ELIZABETHE, PRISONNER ${ }^{35}$

Instead of writing about her imprisonment, Elizabeth was more anxious to write her way out of it. In her appeal to her sister Mary, her normally crisp style gives way to a clear desire to spin out words, to play for time: as Paul Johnson comments, "the letter is verbose, dominated by her evident horror of the Tower." ${ }^{36}$ She seems to have envisaged the letter as merely an unsatisfactory substitute for a personal interview:

The letter from Elizabeth to Mary shows how terrified she was at that time.

The handwriting so praised by Roger Ascham is scrawled and uneven; she filled only one sheet and part of another, and drew wavering diagonal lines across that second page so that nothing could be added by anyone bent on forgery. In her letter Elizabeth reiterates her innocence and asks to be allowed to see Mary personally to plead her case; she cites instances of people who have been condemned because they were denied the chance to speak to the ruler. ${ }^{37}$

For Elizabeth, imprisonment here is figured as the unwritable - indeed the paper must be disfigured to prevent further inscription of it. Nothing speaks so powerfully as those criss-cross lines of the need to control any writing of that which she herself cannot and does not wish to write, and nothing speaks so strongly of the problematic of the recuperation of meaning from the blank page of imprisonment. Or perhaps one other prisoner images it even better: Lord Guilford Dudley, husband of Lady Jane Grey, carved into the wall of his cell an elaborate family tree, complete with verse morals and mottos, which can still be seen. ${ }^{38} \mathrm{Jane}$, his wife, a devout Protestant, carved nothing at all in her own prison.

\section{Sheffield Hallam University}

\section{Notes}

1. Michel Foucault, Discipline and Punish: The Birth of the Prison, translated by Alan Sheridan (Harmondsworth: Penguin, 1975), p. 120.

2. See Hester W. Chapman, Lady Jane Grey (London: Jonathan Cape, 1962), p. 202.

3. See Jeremy Potter, Pretenders to the English Throne (Totowa, NJ: Barnes and Noble, 1987).

4. For the details of Mary's imprisonment, see Antonia Fraser, Mary Queen of Scots (London: Weidenfeld and Nicolson, 1969), pp. 431-653. 
5. See Rosalind K. Marshall, Queen of Scots (London: HMSO, 1986), pp. 199-200; and Patrick Collinson, The English Captivity of Mary Queen of Scots (Sheffield: Sheffield History Pamphlets, 1987), p. 9.

6. Robin Bell, ed., Bittersweet Within My Heart: The Collected Poems of Mary, Queen of Scots (London: Pavilion, 1992), Meditation on the Inconstancy and Vanity of the World, p. 74. The poems from which I quote are not part of the cache known as the Casket Letter, which are of dubious authenticity (on their provenance, see Jenny Wormald, Mary Queen of Scots: A Study in Failure [London: George Philip, 1988], pp. 175-7).

7. Bittersweet Within My Heart, p. 76.

8. Discipline and Punish, p. 46.

9. Roszika Parker, The Subversive Stitch: Embroidery and the Making of the Feminine (London: The Women's Press, 1984), p. 77.

10. Discipline and Punish, p. 35.

11. On Mary's trial, see Fraser, Mary Queen of Scots, pp. 592-608.

12. See Neville Williams, Elizabeth I, Queen of England (London: Weidenfeld and Nicolson, 1967), p. 281.

13. Fraser, Mary Queen of Scots, p. 630. For the details of Mary's execution, see Camille Naish, Death Comes to the Maiden: Sex and Execution 1431-1933 (London: Routledge, 1991), pp. 63-65, and Frances E. Dolan, Dangerous Familiars: Representations of Domestic Crime in England 1550-1700 (Ithaca: Cornell University Press, 1994), p. 87; Mary is also discussed on pp. 42-5.

14. For other examples of the perception of Mary as a martyr, see Wormals, Mary Queen of Scots, pp. 13-14.

15. Fraser, Mary Queen of Scots, p. 630.

16. See Sir Philip Sidney, The Countess of Pembroke's Arcadia, edited by Maurice Evans (Harmondsworth: Penguin, 1977), p. 484.

17. I quote from the version in Thomas Percy, Reliques of Ancient English Poetry, edited by Henry B. Wheatley [1886] (New York: Dover, 1966), pp. 219-220.

18. Elizabeth Balestrieri, "Prison/Anti-Prison: The Writings of Elizabeth I and Marguerite de Navarre," in Continental, Latin-American and Francophone Women Writers, Vol. II, edited by Ginette Adamson and Eunice Myers (Lanham, MD: University Press of America, 1990), pp. 115-22; p. 115.

19. Balestrieri, "Prison/Anti-Prison," p. 117.

20. Balestrieri, "Prison/Anti-Prison," p. 116.

21. See Abel Lefranc, Les idées religieuses de Marguerite de Navarre (Geneva: Slatkine Reprints, 1969), p. 78.

22. Samuel Putnam, Marguerite of Navarre (New York: Coward-McCann, 1935), p. 280. 
23. Quoted in Putnam, Marguerite of Navarre, p. 203.

24. Lefranc, Les idées religieuses, p. 28.

25. Lefranc, Les idées religieuses. p. 68.

26. Quoted in Lefranc, Les idées religieuses, p. 68.

27. Quoted in Lefranc, Les idées religieuses, p. 69.

28. Paul Johnson, Elizabeth I: A Study in Power and Intellect (London: Weidenfeld and Nicolson, 1974), p. 50.

29. Frederick Chamberlin, The Sayings of Queen Elizabeth (London: The Bodley Head, 1923), p. 7. For a lucid discussion of the authenticity of Elizabeth's sayings see Frances Teague, "Queen Elizabeth in Her Speeches," in Gloriana's Face, edited by S.P. Cerasano and Marion Wynne-Davies (Hemel Hempstead: Harvester Wheatsheaf, 1992), pp. 63-75; p. 66.

30. Chamberlin, Sayings, p. 215.

31. Chamberlin, Sayings, p. 224.

32. Chamberlin, Sayings, p. 276.

33. Frances Teague, "Elizabeth I, Queen of England," in Women Writers of the Renaissance and the Reformation, edited by Katharina M. Wilson (Athens: University of Georgia Press, 1987), pp. 522-547; p. 529.

34. Tucker Brooke, “Queen Elizabeth's Prayers," Huntington Library Quarterly, 2 (1938), p. 69.

35. Percy, Reliques, p. 138.

36. Johnson, Elizabeth I, p. 46.

37. Quoted in Susan Bassnett, Elizabeth I: A Feminist Perspective (Oxford: Berg, 1988), p. 31. For Elizabeth's general concern about the control of the meanings produced about her, see Susan Frye, Elizabeth I: The Competition for Representation (Oxford: Oxford University Press, 1993).

38. On the composition and meaning of this see Chapman, Lady Jane Grey, pp. 203-204. 